\title{
Correlation Between Age and Food Intake Containing Purine Toward The Incidence of Hyperuricemia in Fishermen in Batukaras Village, Cijulang District, Pangandaran 2016
}

\author{
Slamet Sudi Santoso, Andre Bastiazeno \\ Medicine Program \\ Faculty of Medicine and Health \\ University of Muhamadiyah Jakarta \\ Jakarta, Indonesia
}

\begin{abstract}
Enhancement of uric acid levels (hyperuricemia) can cause disturbances in the human body as feeling weary in the joints and is often accompanied by the onset of extreme pain for the sufferer. In social charity programme research conducted by Faculty of Medicine and Health, University of Muhammadiyah Jakarta in August 2016 found that there were an enhancement of uric acid levels (hyperuricemia) in fishermen in Batukaras Village Cijulang District, Pangandaran as many as 57 people who have high levels of uric acid (hyperuricemia). The study design was cross sectional and used descriptive analytic method, by total sampling 52 respondents. The study was conduct in Oktober 2016 in Batukaras Village Cijulang district - Pangandaran. Respondents who suffered from hyperuricemia as many as 38 people with the most age above 40 years as many as 29 people. Chisquare test states that there is a significant correlation between the intake of foods containing purines toward the incidence of hyperuricemia, while there is no correlation between age toward the incidence of hyperuricemia. Respondents who suffered from hyperuricemia as many as 38 people at most age over 40 . Food containing high purine become the highest factor that led to the incidence of hyperuricemia followed by medium purine and low purine.
\end{abstract}

\section{Keywords-age; food intake; high purine; hyperuricemia}

\section{INTRODUCTION}

Uric acid is the final result of purine's metabolism. Purine is one of the components of nucleid acid contained in body's nucleus. The enhancement of uric acid levels can cause disturbances in the human body such as the feeling of sore in the joints. This is caused by acummulation of crystals in the area due to high levels of uric acid in the blood. Frequently, people called this disease as gout or known better in the community as called uric acid. Hyperuricemia is caused by excessive purine's synthesis in the body due to irregular eating patterns and the process of uric acid's excretion is impaired. Factors that allegedly also affect the disease are diet, weight, and lifestyle [1].

The prevalence of Hyperuricemia in the community varies greatly, Choi et al in Andry, Saryono, Arif Setyo Upoyo (2009) investigates gout in the male health worker population in
United States, which include dentists, optometrists, osteopaths, pharmacists, and veterinarian. The population is between 40 and 75 years old. From the result of his study after 12 years, he founnd 730 new gout cases. They found an increased risk of gout when respondents ate meats and seafoods in large amounts. 2 In a study by Nan and colleagues at 2006 in China, prevalence of Hyperuricemia was 25,3\% of adults aged 20-74 years old [2].

The first research about gout in Indonesia, Van den Horst in Andry, Saryono, Arif Setyo Upoyo (2009) found 15 cases of severe gout in poor communities in Java.2 Then Darmawan in Andry Saryono, Arif Setyo Upoyo (2009) in Bandungan, Central Java, were doing research among 4.683 people aged 15 45 years old, $0,8 \%$ suffering from uric acid $(0,7 \%$ male and $0.05 \%$ female) and some of them have reached the stage of gout. It is also need to know that in Indonesia gout arthtritis is suffered at an earlier age compared to western countries. $32 \%$ of gout attacks occured under the age of 34 years old, while abroad on average suffered by men over the age [2].

Based on the research of social charity programme of Medicine and Health Faculty of Muhammadiyah Jakarta University on August 2016 was found that there were 57 people suffered from an enhancement of uric acid (hyperuricemia) in Batukaras Village, Cijulang Subdistrict, Pangandaran.

According to the Vitahealth Team in 2004 in Andry, Saryono, Arif Setyo Upoyo (2009), risk factors that caused hyperuricemia are age, excessive purine intake, excessive alcohol cunsumption, obesity, hypertension, heart disease, and impaired renal function. While Krisnatuti et al in Andry, Saryono, Arif Setyo Upoyo (2009) said that one of the causes, which affect uric acid level was exercise or physical activity. The enhancement of uric acid levels also being strong predictorof death due to cardiovascular damage [2].

Based on the description above, we are interested to know the correlation between age and food intake containing purine on the incidence of Hyperuricemia in fishermen in Batukaras 
Village, Cijulang District, Pangandaran, West Java at year 2016.

\section{METHODS}

This research is analytical descriptive research with cross sectional study design, which studying correlation between independent variable (age and food intake containing purine) and dependent variable (Hyperuricemia) through instantaneous measurement or only once and done at the same time. Cross sectional design is used based on the purpose of research that is to know the correlation between age and food intake containing purine on the incidence of hyperuricemia in fishermen who follow the social activities in Batukaras Village, Cijulang District, Pangandaran. The sample used in this study by using the $\mathrm{Z}$ test which has different two proportions as follows :

$$
\begin{aligned}
& n=\frac{\left(z_{1-\alpha} \sqrt{2 P(1-P)}+z_{1-\beta} \sqrt{P_{1}\left(1-P_{1}\right)+P_{2}\left(1-P_{2}\right)}\right)^{2}}{\left(P_{1}-P_{2}\right)^{2}} \\
& n=\frac{(1,96 \sqrt{1,015(1-1,015)}+1,84 \sqrt{0,8(1-0,8)+0,43(1-0,43)})^{2}}{(0,80-0,48)^{2}}=26 \times 2=52
\end{aligned}
$$

\section{Notes :}

$\mathrm{N}=$ The minimum sample size required in the study

$\mathrm{Z} 1-\alpha / 2=$ Confidence Interval $/ \mathrm{CI}(95 \%)$

$\mathrm{A}=$ Degree of significance / level of significance $(5 \%)$

$\mathrm{Z1}-\beta=$ Strength of Test $(80 \%)$

$\mathrm{P} 1=$ Male fishermen who have high uric acid levels $(0,80)$

$\mathrm{P} 2$ = Male fishermen who have normal uric acid levels $(0.43)$

From the calculation of the formula, obtained the number of samples were 26 people. Then multiplied by two thus becoming 52 because of the formula used two proportions.

\section{RESULT}

\section{A. Univariate Analysis}

1. Description of Hyperuricemia Incidence in Fishermen in Batukaras Village 2016

Hyperuricemia incidence in fishermen in Batukaras Village was known based on examination of uric acid levels using GCU check tool. Then tested by ordinal scale univariate statistic, so it can be known about the frequency distribution of hyperuricemia incidence in fishermen as shown in table 1.

Based on table 1 above, it can be seen that as many as 14 fishermen $(26.9 \%)$ did not suffered from hyperuricemia. And as many as 38 fishermen (73.1\%) suffered from hyperuricemia. Hyperuricemia is caused by many factors such as age and food intake containing purine. Hyperuricemia is more common in men over the age of 40, as uric acid levels in men tend to increase by the age. The enhancement of uric acid levels was because of aging process started at age 40 years [3].
TABLE 1. DESCRIPTION OF HYPERURICEMIA INCIDENCE IN FISHERMEN IN BATUKARAS VILLAGE 2016

\begin{tabular}{|c|c|c|}
\hline $\begin{array}{c}\text { Hyperuricemia } \\
\text { Incidence }\end{array}$ & $\begin{array}{c}\text { Amount } \\
(\mathbf{n})\end{array}$ & $\begin{array}{c}\text { Percentage } \\
(\mathbf{\%})\end{array}$ \\
\hline $\begin{array}{c}\text { Negative } \\
\text { Hyperuricemia }\end{array}$ & 14 & 26,9 \\
\hline $\begin{array}{c}\text { Positive } \\
\text { Hyperuricemia }\end{array}$ & 38 & 73,1 \\
\hline Total & $\mathbf{5 2}$ & $\mathbf{1 0 0}$ \\
\hline
\end{tabular}

Another factor that greatly affects the incidence of hyperuricemia is food intake containing excessive purine such as consuming the following foods with frequent frequencies, as example sardine, liver, kidney, and brain. While foods that have low purine content are beans, wheat, beans, and others Fishermen often consume foods containing purine and coffee that can trigger the incidence of hyperuricemia [4].

2. Description of Fisherman's Age in Batukaras Village Year 2016

TABLE 2. DESCRIPTION FISHERMEN'S AGE IN BATUKARAS VILLAGE YEAR 2016

\begin{tabular}{|c|c|c|}
\hline Age & $\begin{array}{c}\text { Amount } \\
(\mathrm{N})\end{array}$ & $\begin{array}{c}\text { Percentage } \\
(\%)\end{array}$ \\
\hline$<40$ years & 11 & 21,2 \\
\hline$\geq 40$ years & 41 & 78,8 \\
\hline Total & 52 & 100 \\
\hline
\end{tabular}

Description of Fishermen's Age based on the results of research in table 2, it is known that most of fishermen's age were 40 years and over, as many as 41 people (78.8\%). While fishermen who aged under 40 years as many as 11 people $(21.2 \%)$.

3. Description of Food Intake Containing Purine in Fishermen in Batukaras Village 2016

TABLE 3 DESCRIPTION OF FOOD INTAKE CONTAINING PURINE IN

\begin{tabular}{|c|c|c|c|}
\hline No & Food Intake & $\begin{array}{c}\text { Amount } \\
\text { (N) }\end{array}$ & $\begin{array}{c}\text { Percentage } \\
(\%)\end{array}$ \\
\hline 1. & Low Risk & 19 & 36.5 \\
\hline 2. & High Risk & 33 & 63.5 \\
\hline \multicolumn{2}{|r|}{ Total } & 52 & 100 \\
\hline
\end{tabular}
FISHERMEN IN BATUKARAS VILLAGE 2016 
Based on the results of the research in table 3, it can be seen that the proportion of low-risk fishermen who suffered from hyperuricemia due to consumption of foods containing purine was as many as 19 people $(36.5 \%)$. While the proportion of fishermen who are at high risk of hyperuricemia due to the consumption of foods containing purine were as many as 33 people $(63.5 \%)$.

\section{B. Bivariate Analysis}

1. Correlation between Age toward Incidence of Hyperuricemia in Fishermen in Batukaras Village 2016

Based on table 4, it can be seen that fishermen aged under 40 years mostly suffered from the incidence of hyperuricemia were 9 people $(64.3 \%)$, while there were 5 people $(35.7 \%)$ who did not suffered from the incidence of hyperuricemia. There were 29 fishermen $(76.3 \%$ ) who were over 40 years old suffered from hyperuricemia and the rest of 9 people $(23.7 \%)$ did not suffered from hyperuricemia.

TABLE 4 DESCRIPTION OF CORRELATION BETWEEN AGE TOWARD INCIDENCE OF HYPERURICEMIA IN FISHERMEN IN BATUKARAS VILLAGE 2016

\begin{tabular}{|c|c|c|c|c|c|c|c|c|}
\hline \multirow{3}{*}{ Age } & \multicolumn{4}{|c|}{$\begin{array}{c}\text { Incidence of } \\
\text { Hyperuricemia }\end{array}$} & \multirow{2}{*}{\multicolumn{2}{|c|}{ Total }} & \multirow{3}{*}{$P_{\text {value }}$} & OR \\
\hline & \multicolumn{2}{|c|}{ Negative } & \multicolumn{2}{|c|}{ Positive } & & & & $95 \%$ \\
\hline & $\mathbf{n}$ & $\%$ & $\mathbf{n}$ & $\%$ & $\mathbf{n}$ & $\%$ & & CI \\
\hline $\begin{array}{c}<40 \\
\text { years, }\end{array}$ & 5 & 35.7 & 9 & 64.3 & 14 & 100 & \multirow{3}{*}{0.005} & \multirow{3}{*}{$\begin{array}{r}0.879 \\
(0.200- \\
3.859)\end{array}$} \\
\hline $\begin{array}{l}\geq 40 \\
\text { years }\end{array}$ & 9 & 23.7 & 29 & 76.3 & 38 & 100 & & \\
\hline Total & 14 & 26.9 & 38 & 73.1 & 52 & 100 & & \\
\hline
\end{tabular}

Based on the result of chi square statistic test, it is known that age has no significant correlation with the incidence of hyperuricemia $(\alpha \geq 0.005)$ (by $\mathrm{P}$ value $=0.485)$. Based on the calculation of risk estimate obtained OR $=0.879(95 \% \mathrm{CI}$ 0.200-3.859), there is no significant correlation between age toward the incidence of hyperuricemia in fishermen. Fishermen aged 40 years and older were at risk 0.8 times greater to be suffered from hyperuricemia compared with fishermen aged under 40 years.

\section{The Correlation between Food Intake Containing}

Purine toward the Incidence of Hyperuricemia in Fishermen in Batukaras Village 2016

Based on the results in table 5 , it can be seen that the proportion of fishermen who consume foods containing high purine, there were 28 people $(84.8 \%)$ who suffered from hyperuricemia and as many as 5 people $(15.2 \%)$ did not suffered from hyperuricemia. While the proportion of fishermen who consume foods containing low purine, there were 10 people $(52.6 \%)$ who suffered from hyperuricemia and 9 people $(47.4 \%)$ who did not suffered from hyperuricemia.
TABLE 5 DESCRIPTION OF CORRELATION BETWEEN FOOD INTAKE CONTAINING PURINE TOWARD THE INCIDENCE OF HYPERURICEMIA IN FISHERMEN IN BATUKARAS VILLAGE 2016

\begin{tabular}{|c|c|c|c|c|c|c|c|c|}
\hline \multirow{3}{*}{$\begin{array}{c}\text { Food Intake } \\
\text { Containing } \\
\text { Purine }\end{array}$} & \multicolumn{4}{|c|}{$\begin{array}{r}\text { Incidence of } \\
\text { Hyperuriemia }\end{array}$} & \multirow{2}{*}{\multicolumn{2}{|c|}{ Total }} & \multirow{3}{*}{$\begin{array}{c}\text { Pvalu } \\
e\end{array}$} & OR \\
\hline & \multicolumn{2}{|c|}{ Negative } & \multicolumn{2}{|c|}{ Positive } & & & & \multirow[t]{2}{*}{$95 \% \mathrm{CI}$} \\
\hline & $\mathrm{n}$ & $\%$ & $\mathrm{n}$ & $\%$ & $\mathrm{n}$ & $\%$ & & \\
\hline $\begin{array}{c}\text { Low } \\
\text { Purine }\end{array}$ & 9 & 47.4 & 10 & 52.6 & 19 & 100 & \multirow{3}{*}{0.028} & \multirow{3}{*}{$\begin{array}{r}5.040 \\
(1.360- \\
18.68)\end{array}$} \\
\hline $\begin{array}{r}\text { High } \\
\text { Purine }\end{array}$ & 5 & 15.2 & 28 & 84.8 & 33 & 100 & & \\
\hline Total & 14 & 26.9 & 38 & 73.1 & 144 & 100 & & \\
\hline
\end{tabular}

Based on result of chi square statistic test, it was known that food intake containing purine had a significant correlation with the incidence of hyperuricemia $(\alpha \leq 0.05$ or $\mathrm{P}$ value $=0.028)$. Based on the calculation of risk estimation, $\mathrm{OR}=5.040(95 \%$ CI $1.360-18.682)$, which means that fishermen who consume foods containing high purine had a risk of 5.040 times greater to be suffered from hyperuricemia than fishermen who consume foods containing low purine.

\section{DISCUSSION}

Uric acid is final product of purine metabolism. Under normal circumstances, $90 \%$ of adenine nucleotide metabolites, guanine, and hypoxanthine will be reused so that they will reshape into adenosine monophosphate (AMP), inosine monophosphate (IMP), and guanosine monophosphate (GMP) by adenine phosphoribosyl transferase (APRT) and hypoxanthine guanine phosphoribosyl transferase (HGPRT). Only the remainder that will be converted to xanthine and then converted to uric acid by xanthine oxidation enzyme [3].

As if there was an enhancement in uric acid levels above normal so that made a formation of excessive uric acid, decreased excretion of uric acid or a combination of both, it can cause hyperuricemia [6,7].

Age is a variable that allegedly associated with the incidence of hyperuricemia. Uric acid levels in men tend to increase by the age. Enhancement of uric acid levels are generally due to the aging process that begins at the age of 40 years. Hence the possibility of hyperuricemia due to aging factors according toward age [3].

However, based on the results of the research, it was known that there was no significant correlation between age toward the incidence of hyperuricemia. This was most likely ocuured due to differences in the data filling of age at the time of social charity programme and at the time of the research due to age uncertainty by the respondent. In addition to age, foods which containing high purine were able to increase uric acid level in the urine around $0.5-0.75 \mathrm{gr} / \mathrm{ml}$. Examples of foods containing high purine such as sardines, liver, kidney, and brain. While foods which containing low purine such as nuts, wheat, beans, and others [5]. 
Consumption of foods containing purine in fishermen was a very important and significant variable to the incidence of hyperuricemia in fishermen in Batukaras village, because most fishermen consume foods containing high purine such as meat / beef extract daily with frequencies between 1-3x daily, in addition they also consume fish, vegetables such as spinach, cassava leaves, kale, eggs and coffee with frequent intake frequency can also trigger hyperuricemia in fishermen in Batukaras village [5].

Based on result of chi square statistic test, it is known that food intake containing purine had a significant correlation with the incidence of hyperuricemia $(\alpha \leq 0.05$ or Pvalue $=$ 0.028). Based on the calculation of risk estimation, $\mathrm{OR}=5.040$ (95\% CI 1.360 - 18.682), which means that fishermen who consume foods containing high purine had a risk of 5.040 times greater to be suffered from hyperuricemia than fishermen who consume foods containing low purine. This was approprite with previous research conducted by Fauzia [4], incidence of hyperuricemia can be happen also because of uncertain income of the fishermen, which can cause fishermen to consume fish by their own catch, vegetables, eggs and coffee by more affordable price due to their uncertain income.

\section{CONCLUSION}

The prevalence of fishermen who suffered from Hyperuricemia in Batukaras Village, Cijulang District, Pangandaran Regency in 2016 is 38 people $(73.1 \%$ ) and by the age more than 40 year were 29 people $(55.7 \%)$. Based on the results of research about the correlation between food intake containing purine toward the incidence of hyperuricemia, Ho was rejected, it means there was a correlation between food intake containing purine on the incidence of hyperuricemia with value of $P$ value $(0.028)$ while for the correlation between age toward the incidence of hyperuricemia, Ho accepted, it means there was no correlation between age toward the incidence of hyperuricemia with the value of $\mathrm{P}$ value (1.000).

\section{REFERENCES}

[1] Price, P, A \& Wilson, L, M. Gout, Pathophysiology (Gout Patofisiologi Konsep klinis proses- proses penyakit). Jakarta: EGC; 2005.

[2] Andry, Saryono, Arif Setyo Upoyo. Analysis of factors affecting uric acid levels in office workers in Karang Turi village, Bumiayu district, Brebes district. Purwokerto (Analisis faktor-faktor yang mempengaruhi kadar asam urat pada pekerja kantor di desa Karang Turi, Kecamatan Bumiayu, Kabupaten Brebes. Purwokerto), J Keperawatan Soedirman (The Soedirman Journal of Nursing), vol. 4, no.1, Mar 2009.

[3] Setiati Siti, Harimurti Kuntjoro, Govinda, A.R. The Aging Process and Clinical Implications. In: Aru W Sudoyo, Bambang Setiyohadi, Marcellus Simardibrata K, Siti Setiadi (Ed): Textbook of Disease In Volume I, (Proses Menua dan Implikasi Kliniknya. Dalam: Aru W Sudoyo, Bambang Setiyohadi, Marcellus Simardibrata K, Siti Setiadi(Ed): Buku Ajar Ilmu Penyakit Dalam Jilid I, hal. 757, Jakarta: Interna Publishing; 2009.

[4] Fauzia Gina. Factors Associated with Uric Acid Level In Women Member Assembly Taklim Al Amin District Cilandak. Research Report - Jakarta: Faculty of Public Health, University of Indonesia (FaktorFaktor yang Berhubungan dengan Kadar Asam Urat Pada Wanita Anggota Majelis Taklim Al Amin Kecamatan Cilandak. Jakarta: Fakultas Kesehatan Masyarakat, Universitas Indonesia); 2010

[5] S. Silbernagl, F. Lang. Gout. In: Titiek Resmisari, Liena (Ed): Colored Text and Atlas of Pathophysiology (Gout. Dalam: Titiek Resmisari, Liena(Ed): Teks dan Atlas Berwarna Patofisiologi), pp. .250. Jakarta: EGC; 2006

[6] Harjanti, R.T. The Effect of Giving Soybean Flour on Uric Acid Level in White Rat Blood. Thesis. Semarang: Faculty of Mathematics and Natural Sciences, Semarang State University (Pengaruh Pemberian Tepung Kedelai Terhadap Kadar Asam Urat dalam Darah Tikus Putih [skripsi]. Semarang: Fakultas Matematika dan Ilmu Pengetahuan Alam, Universitas Negeri Semarang); 2006.

[7] Mustafiza Pramadya Vardhani. Relationship between Hyperurisemia with Hypertension. Thesis. Surakarta: Faculty of Medicine, Sebelas Maret University (Hubungan antara Hiperurisemia dengan Hipertensi[skripsi]. Surakarta: Fakultas Kedokteran, Universitas Sebelas Maret); 2010. 